\title{
Uji Briket Bioarang yang Diproses Menggunakan Arang Kotoran Sapi, Arang Kotoran Kambing dan Arang Kotoran Ayam dengan Penambahan Sekam Padi terhadap Kualitas yang Dihasilkan
}

\author{
Emilia Rafu Berek \\ Fakultas Pertanian, Universitas Timor, Kefamenanu, TTU - NTT, Indonesia, email: berekemilitarafu@gmail.com
}

\section{Article Info}

\section{Article history:}

Received 01 Juni 2019

Received in revised form 17 Agustus 2019 Accepted 12 Oktober 2019

DOI

https://doi.org/10.32938/ja.v4i4.710

Keywords:

Kualitas brike

Kotoran ternak

Sekam padi

\section{Abstrak}

Penelitian ini telah dilaksanakan di Laboratorium Fakultas Pertanian Universitas Timor, Propinsi Nusa Tenggara Timur yang berlangsung selama 2 bulan terhitung dari 28 desember 2018 sampai dengan 28 Februari 2019. Tujuan dari penelitian ini adalah untuk mengetahui kualitas briket bioarang yang diproses menggunakan arang kotoran sapi, kotoran kambing dan kotoran ayam dengan penambahan sekam padi. Penelitian ini menggunakan Rancangan Acak Lengkap (RAL) dengan 3 perlakuan dan masing-masing perlakuan diulang sebanyak 5 kali sehingga terdapat 15 satuan unit percobaan. Komposisi ketiga briket tersebut memiliki masa jenis yang sama (300 gram) adapun perlakuan yang diuji terdiri dari: $\left(\mathrm{P}_{0}\right)=$ Kotoran Sapi $80 \%+$ sekam padi $10 \%+$ tepung kanji $10 \%$, $\left(\mathrm{P}_{1}\right)=$ Kotoran Kambing $80 \%+$ sekam padi $10 \%$ + tepung kanji $10 \%$ dan $\left(\mathrm{P}_{2}\right)=$ Kotoran Ayam $80 \%+$ sekam padi $10 \%+$ tepung kanji $10 \%$. Hasil sidik ragam anova menunjukkan bahwa parameter kadar air dan kadar abu tidak menunjukkan beda yang nyata antar perlakuan sedangkan laju pembakaran dan nilai kalor menunjukkan beda yang nyata antar perlakuan $(\mathrm{P}<0.05)$. Disimpulkan bahwa kualitas briket terbaik dihasilkan oleh briket yang dibuat dari bahan dasar kotoran sapi dengan penambahan sekam padi yang menghasilkan kadar air $(35,69 \%)$, kadar abu $(19,72 \%)$ dan nilai kalor $(3379 \mathrm{kal} / \mathrm{g})$ sedangkan laju pembakaran terbaik adalah briket kotoran kambing dengan campuran sekam padi $10 \%$

\section{Pendahuluan}

Indonesia berpotensi sebagai lumbung bioenergi dunia karena indonesia mempunyai daerah yang sangat subur untuk membudidayakan hewan ternak dan pertanian yang dapat dimanfaatkan sebagai bahan baku pembuatan bioarang. Salah satunya adalah energi yang terbarukan merupakan sumber energi yang berpotensi tinggi sebagai pengganti energi minyak bumi, yaitu dengan memanfaatkan limbah atau limbah pertanian, limbah pasar maupun limbah peternakan. Pemanfaatan limbah peternakan dan pertanian merupakan salah satu alternatif yang sangat tepat untuk mengatasi naiknya harga dan kelangkahaan bahan bakar minyak (Syahrul et al., 2015). Namun sampai saa ini pemanfaatan kotoran ternak dan limbah pertaniaan sebagai bahan bakar alternatif belum dilakukan secara optimal.Tingkat kebutuhan akan energi di Indonesia terus meningkat setiap tahunnya, namun tak sebanding dengan jumlah energi yang ada untuk mensuplai kebutuhan tersebut. Hal in dikarenakan jumlah penduduk yang terus bertambah, pertumbuhan ekonomi, penggunaan energi yang tidak efisien, serta pengelolaan dalam memanfaatkan sumber energi yang ada masih belum maksimal. Dibutuhkan energi baru terbarukan sebagai alternatif yang dapat mengganti penggunaan energi fosi sebagai bahan bakar.

Salah satu energi alternatif tersebut adalah pemanfaatan biomassa sebagai briket dari kotoran ternak salah satunya adalah briket bioarang. Brike bioarang adalah arang yang diolah lebih lanjut menjadi bentuk briket (penampilan dan kemasan yang lebih menarik) yang dapat digunakan untuk keperluan energi alterntif sehari-hari sebagai pengganti minyak tanah dan gas elpiji. Briket arang mempunyai banyak kelebihan yaitu bila dikemas dengan menarik akan mempunyai nilai ekonomi yang lebih tinggi dengan arang kayu yang dijual di pasar tradisional, briket mempunyai panas yang lebih tinggi, tidak berbau, bersih, dan tahan lama (Widodo et al., 2010). Briket arang dapa dibuat dari bahan atau limbah organik yang berasal dari potensi dan peternakan.

Limbah pertanian yang dapat dimanfaatkan adalah sekam padi sedangkan limbah peternakan berupa kotoran ternak namun diduga bahwa kualitas dari briket yang dibuat daya bahan berbeda diduga akan mempunyai kualitas yang berbeda pula. Tujuan dari penelitian ini adalah untuk mengetahu kualitas briket bioarang yang diproses menggunakan arang kotoran kambing, kotoran sapi dan kotoran ayam dengan penambahan sekam padi.

\section{Metode}

\subsection{Waktu dan Lokasi Penelitian}

Penelitian berlangsung pada bulan Desember tahun 2018 - Februari tahun 2019, dan dilakukan pada dua lokasi pembuatan briket bioarang di Laboratorium Fakultas Pertaniaan Unimor, sedangkan pengujian nilai kalor dilakukan di LaboratoriumFakultas Teknik Sipil Undana.

\subsection{Alat dan Bahan}

Alat-alat yang digunakan dalam penelitian ini adalah kiln drum, kuali dan pengaduk, tungku, lesung, bahan pembuat briket, ayakan, alat pencetak briket, tanur, ember dan kamera. Selain itu, peralatan dalam laboratorium adalah sebagai berikut : cawan, oven listrik dan bomb calorimeter.Bahanbahannya adalah arang kotoran kambing, arang kotoran sapi, arang kotoran ayam, sekam padi tepung kanji dan air secukupnya.

\subsection{Rancangan Penelitian}

Penelitian ini menggunakan model eksperimen desain dengan menggunakan Rancangan Acak Lengkap (RAL) dengan 3 perlakuan dan masing-masing perlakuan diulang sebanyak 10 kali. Komposisi ketiga briket tersebut memiliki masa jenis yang sama (300 gram) adapun perlakuan yang diuji terdiri dari:

$\mathrm{P}_{0}=$ Kotoran kambing $80 \%+$ sekam padi $10 \%+$ tepung kanji $10 \%$

$\mathrm{P}_{1}=$ Kotoran sapi $80 \%+$ sekam padi $10 \%+$ tepung kanji $10 \%$
$\mathrm{P}_{2}=$ Kotoran ayam $80 \%+$ sekam padi $10 \%+$ tepung kanji $10 \%$

\subsection{Prosedur Penelitian}

2.4.1 Prosedur Pembuatan Arang Kotoran Kambing, Kotoran Sapi, Kotoran Ayam dan sekam padi

Bahan baku seperti kotoran kambing, sapi, ayam serta sekam padi dikeringkan di bawah sinar matahari sampai benar-benar kering. Kotoran kemudian dimasukkan ke dalam Kiln Drum (tempat pembakaran) secara terpisah, lalu dilakukan pembakaran yang dibantu dengan nyala api dari dasar tabung sampai semua kotoran dan sekam padi terbakar menjadi arang. Setelah semua bahan terbakar menjadi arang, api di dasar tabung dipadamkan, lalu 2015)

\subsubsection{Prosedur Pembuatan Briket}

Prosedur pembuatan briket diadopsi dari Sarjono dan Ridlo (2013)

a. Bahan baku berupa kotoran ternak dan sekam adi yang telah kering ditumbuk sampai menjadi serbuk

b. Serbuk kotoran yang sudah ditumbuk diayak dengan ukuran 40 mesh

c. Serbuk ternak dan serbuk sekam dicampurkan sesuai komposisi

d. Untuk perekat, tepung tapioka yang sudah ditimbang dan dimasukkan pada air yang sudah di didihkan sebelumnya dan diaduk hingga merata.

e. Setelah perekat siap, dilakukan pencampuran antara bahan baku yang sudah disaring dengan perekat kanji. pencampuran dilakukan sampai adonan merata, terdapat 3 macam campuran adonan briket dengan persentase berikut: arang kotoran kambing, $80 \%$, sekam padi $10 \%$ dan kanji $10 \%$. Kotoran sapi $80 \%$, sekam padi $10 \%$ dan kanji $10 \%$, Kotoran ayam $80 \%$, sekam padi $10 \%$ dan kanji $10 \%$

f. Briket dicetak dengan memasukkan adonan ke dalam alat cetak dengan bentuk cetakan adalah silinder, dan hasil ukuran briket adalah tinggi $5 \mathrm{~cm}$ dan diameter $6 \mathrm{~cm}$.

g. Hasil cetakan briket dikeluarkan kemudian dilakukan penimbangan untuk memperoleh berat awal dari briket sebelum dilakukan proses pengeringan.

h. Data berat, tinggi dan kuat tekan dari briket dicatat dan dikelompokkan setelah dicetak

i. Briket dikeringkan dengan cara dijemur selama selama 4-5 hari.

\subsection{Pengambilan Data}

Sesudah briket selesai dibuat, selanjutnya akan dihitung kadar air sampel yang ditentukan dengan cara dioven, dengan metode penimbangan bahan dengan timbangan analisis $10 \mathrm{~g}$ dalam cawan plastik yang telah diukur bobot keringnya. Kemudian dikeringkan didalam oven pada suhu $105^{\circ} \mathrm{C}$ sampai beratnya konstan, setelah itu, bahan didinginkan didalam desikator dan timbang kembali.

Kadar abu dalam pengujian ini akan diukur dengan metode : sampe ditimbang 10 gram.kemudian dimasukkan kedalam cawan porselen, sampe dipanaskan sampai menjadi arang dan tidak mengeluarkan asap dan kemudian diabukan dalam tanur pada suhu $500^{\circ} \mathrm{C}$ sehingga menjadi abu lalu didinginkan di dalam desikator kemudian timbang setelah mencapai suhu ruang. Proses selanjutnya adalah menghitung laju pembakaran briket yang dihitung dengan cara berat briket yang telah dinyalakan dibagi dengan waktu pembakaran sampai briket habis terbakar atau menjadi abu.

Prosedur kerja untuk menentukan nilai kalor adalah sebagai berikut (Putri dan Andasuryani, 2017) :

a. Sampel briket dihancurkan dan ditimbang, kemudian dimasukkan kedalam cawan pembakar tepat dibawah lengkungan kawat sumbu yang kedua ujungnya telah dikaitkan pada kedua elektroda. kambing, sapi, ayam dan sekam padi dibersihkan dari kotoran atau bahan lain, lubang asap ditutup, sampai api benar-benar padam (Sudding dan Jamaludin, 
b. Rangkaian tersebut kemudian dimasukkan kedalam bomb yang sebelumnya telah diisi akuades sebanyak $1 \mathrm{ml}$ kedalam bomb, selanjutnya ditutup rapat dan dialiri gas oksigen melalui katup kurang lebih 35 atm. Bomb dimasukkan kedalam kalorimeter yang telah diisi air sebanyak 2 liter, dan dihubungkan dengan unit pembakar.

c. Kalorimeter (alat yang digunakan untuk mengukur jumlah kalor yang terlibat dalam suatu perubahan atau reaksi kimia ) ditutup dan termometer dipasang pada tutup kalorimeter, sehingga skala pada bagian bawah tepat pada angka $19^{\circ} \mathrm{C}$, temperatur konstan pengaduk listrik dihidupkan dan dibiarkan selama 5 menit, kemudian sumber tegangan arus 23 volt dihidupkan untuk membakar kawat sumbu. Pada saat ini temperatur diamati maka temperatur akan naik dengan cepat, setelah itu konstan dan akhirnya sedikit akan turun, kemudian sumber tegangan pembakar dan pengaduk dimatikan.

\subsection{Variabel Penelitian}

\subsubsection{Kadar Air}

Rumus untuk menghitung kadar air briket :

$b-c$

$\frac{b-c}{b-a} \times 100 \%$

Keterangan :

$\mathrm{a}=$ berat cawan kosong $(\mathrm{g})$

$\mathrm{b}=$ berat cawan + sampel briket $(\mathrm{g})$

$\mathrm{c}=$ berat cawan + sampel briket setelah di oven hingga beratnya konstan (g)

\subsubsection{Kadar Abu}

Rumus untuk menghitung kadar abu briket :

Berat abu

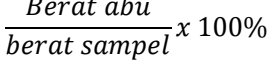

\subsubsection{Laju Pembakaran Briket}

Rumus perhitungan laju pembakaran briket:

$\frac{\text { berat briket }}{\text { waktu sampai briket habis (menit) }} \times 100 \%$

\subsubsection{Nilai Kalor}

Kalor merupakan suatu kuantitas atau jumlah panas yang baik yang diserap maupun dilepaskan oleh suatu benda. Nilai kalor diperoleh dari briket dengan data laboratorium. Rumus menghitung nilai kalor adalah sebagai berikut:

$\mathrm{Q}=\mathrm{m} . \mathrm{c} . \Delta \mathrm{T}$

Ket :

$\mathrm{Q}=$ Panas yang diperlukan untuk menaikkan temperature

$\mathrm{m}$ = Masa bahan bakar

$\mathrm{c} \quad=$ Kalor jenis

$\Delta \mathrm{T}=$ Perbedaan temperature

\subsection{Analisis Data}

Data yang diperoleh dalam penelitian ini dianalisis dengan menggunakan analisis sidik ragam (Anova) sesuai dengan Rancangan Acak Lengkap (RAL). Selanjutnya diuji lanjut denganDuncan Multiple Range Test (DMRT) untuk melihat perbedaan.

\section{Hasil dan Pembahasan}

\subsection{Kadar air}

Pengujian kadar air dilakukan dengan tujuan untuk mengetahui persentase kadar air yang terkandung dalam briket kotoran ternak dengan tambahan sekam padi dan perekat kanji. Gambar 1 menunjukkan bahwa persentase kadar air tertinggi briket dihasilkan dari kotoran ayam dan sekam padi (K2) yaitu sebesar 40,62\%, diikuti briket berbahan dasar kotoran kambing dan sekam padi (K1) sebesar 38,26\% dan kadar air terendah pada briket berbahan dasar kotoran sapi dan sekam padi (K0) 35,69\% Kadar air briket yang dihasilkan dalam penelitian ini belum memenuhi Standar Nasional Indonesia (SNI) yakni lebih besar $>8 \%$, kadar air briket bioarang menurut Standar Nasional Indonesia (SNI) yakni $<8 \%$. Hasil sidik ragam (Anova) menunjukkan bahwa pemberian perlakuan dalam penelitian ini menunjukkan tidak berbeda nyata. Kadar air yang tinggi akan membuat briket sulit dinyalakan pada saat pembakaran dan akan banyak menghasilkan asap, selain itu akan mengurangi temperatur penyalaan dan daya pembakarannya (Hutasoit, 2012).

Hasil uji statistik menunjukkan bahwa perlakuan tidak berpengaruh nyata terhadap persentase kadar air briket. Kadar air yang tergolong tinggi pada briket yang dihasilkan dari penelitian ini disebabkan karena pemberian bahan perekat $10 \%$ sehingga memberikan sumbangan kadar air yang tinggi terhadap briket. Pada umumnya kadar air briket dipengaruhi oleh jenis bahan baku, jenis perekat dan metode pengujian yang digunakan. Bahan baku dalam pembuatan briket akan mempengaruhi kualitas dari briket tersebut. Semakin tinggi kadar air bahan baku maka dalam proses karbonisasi akan lebih banyak kalor yang dibutuhkan untuk mengeluarkan air tersebut menjadi uap sehingga energi yang tersisa dalam arangmenjadi lebih kecil (Rahman et al., 2010). Kadar air sangat menentukan kualitas arang yang dihasilkan, semakin tinggi kadar air maka akan makin banyak kalor yang dibutuhkan untuk mengeluarkan air dari dalam kayu agar menjadi uap sehingga energi yang tersisa dalam arang akan menjadi lebih kecil.

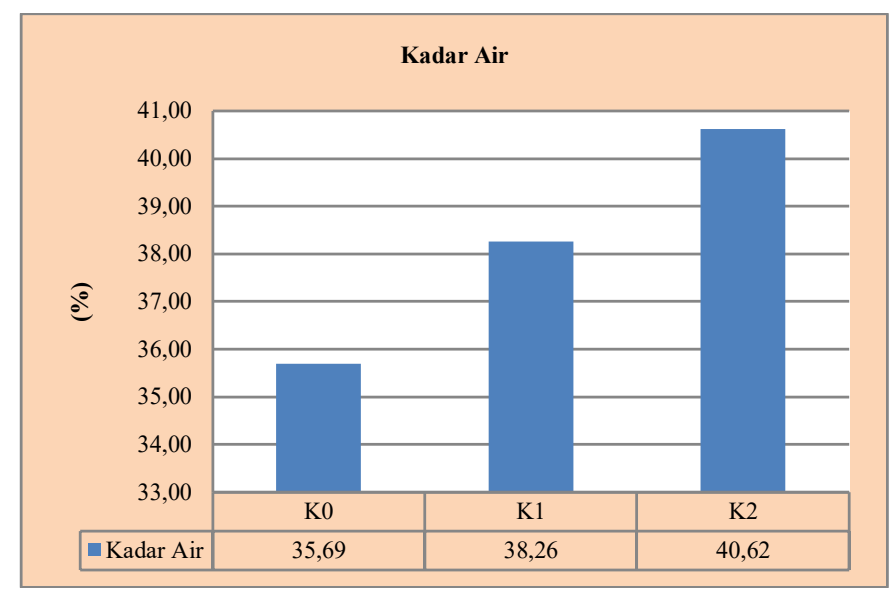

Gambar1. Rataan Kadar Air (\%) Briket dengan Bahan Dasar Kotoran Kambing, Sapi dan Ayam dengan Penambahan Sekam Padi.

\subsection{Kadar abu (\%)}

Abu merupakan bagian akhir atau sisa dari suatu pembakaran dalam ha ini sisa dari hasil pembakaran briket. Salah satu penyusun abu adalah silika yang mana pengaruhnya kurang baik terhadap nilai kalor briket arang yang dihasilkan. Kadar abu briket berpengaruh terhadap nilai kalor dan nilai kadar karbon. Semakin kecil nilai kadar abu maka semakin tinggi nilai kalor dan kadar karbonnya (Putri dan Andarsuryani, 2017).

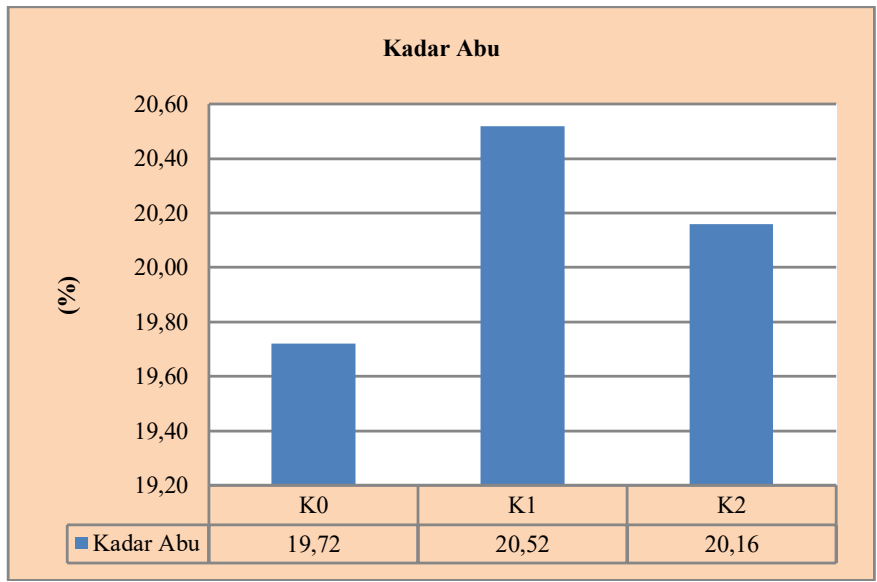

Gambar 2. Rataan Kadar Abu (\%) Briket dengan Bahan Dasar Kotoran sapi, Kambing dan Ayam dengan Penambahan Sekam Padi.

Gambar 2 menunjukkan presentase kadar abu briket tertinggi pada kotoran kambing dan sekam padi (K1) yaitu sebesar 20,52\% diikuti briket berbahan dasar kotoran ayam dan sekam padi (K2) sebesar 20,16\% dan kadar abu terendah pada beriket berbahan dasar kotoran sapi dan sekam padi (K0) $19,72 \%$. Hasil uji statistik menunjukkan bahwa briket kotoran ternak (sapi, kambing dan ayam) dengan penambahan sekam padi tidak berpengaruh nyata terhadap persentase kadar abu yang dihasilkan.

Hal ini ada hubungannya dengan kadar air, dimana jika kadar air yang dihasilkan tinggi maka kadar abu pun ikut tinggi, karena semakin tinggi nilai kadar air maka kadar abu yang dihasilkan semakin tinggi pula. Sarjono dan Ridlo (2013) menyatakan bahwa semakin tinggi jumlah konsentrasi kadar air maka akan semakin tinggi kadar abu pada briket. Hal ini terjadi karena semakin banyak kadar air maka semakin sulit briket terbakar karena masih mengandung kadar air yang lebih, sehingga pada saat akhir pembakaran sisa dari briket tidak sepenuhnya menjadi abu.

Secara umum briket yang dihasilkan pada penelitian ini memiliki nilai kadar abu yang cukup tinggi namun dapat dikategorikan belum memenuh standar nasional (SNI) yakni $>8 \%$. Faktor jenis bahan baku sangat berpengaruh terhadap tinggi rendahnya kadar abu briket arang yang dihasilkan. Hal in dikarenakan bahan baku yang digunakan memiliki komposisi kimia dan jumlah mineral yang berbeda-beda akibatnya kadar abu briket arang yang dihasilkan berbeda pula (Hendra dan Winarni, 2003)

\subsection{Laju pembakaran Briket (g/dtk)}

Pengujian laju pembakaran dilakukan untuk mengetahui efektifitas dari suatu bahan bakar. Menurut Subroto (2007) semakin banyak kandungan volatile matter suatu briket maka semakin mudah biobriket tersebut terbakar, sehingga pembakaran semakin cepat. Selanjutnya Putri dan Andarsuryani (2017) menyatakan bahwa laju pembakaran briket adalah kecepatan briket 
habis sampai menjadi abu. Rataan laju pembakaran briket dapat dilihat pada Gambar 3.

Gambar 3 menunjukkan proses laju pembakaran briket bioarang terbaik pada kotoran ayam (K2) yaitu sebesar $0,44 \%$ diikuti briket berbahan dasar kotoran Sapi (K0) sebesar 0,35\% dan laju pembakaran terendah pada beriket berbahan dasar kotoran kambing (K1) $0,32 \%$. Hasil uji statistik menunjukkan bahwa perlakuan berpengaruh nyata terhadap laju pembakaran $(\mathrm{P}<0,05)$.

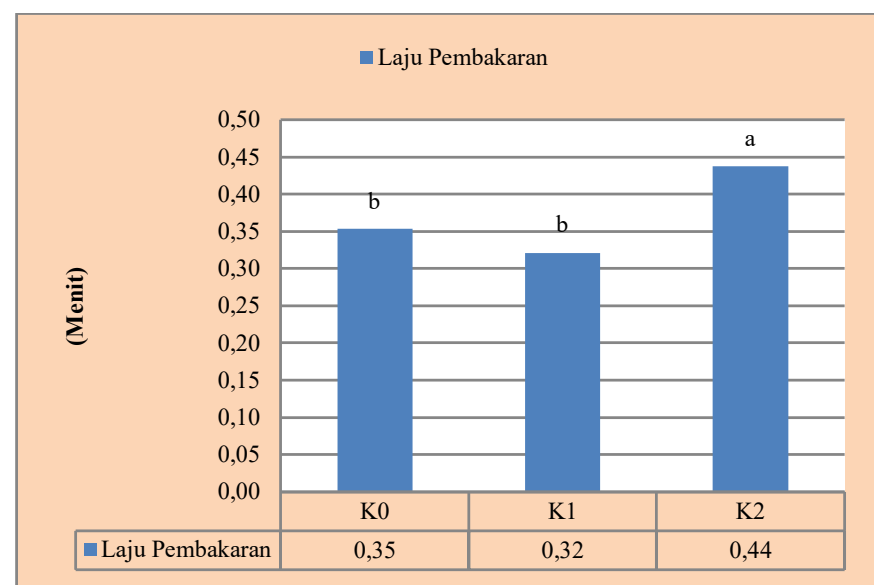

Gambar 3. Rataan Laju Pembakaran Briket (g/dtk) dengan Bahan Dasar Kotoran, Sapi, Kambing dan Ayam dengan Penambahan Sekam Padi; Superskrip yang berbeda gambar menunjukkan sangat berbeda nyata $(\mathrm{P}<0,05)$

Laju pembakaran ini ada hubungannya dengan kerapatan briket, semakin rapat suatu briket maka laju pembakarannya akan lebih lambat demikianpun sebaliknya. Hal ini diperkuat oleh Riseanggara (2008), kerapatan yang lebih tinggi memperlambat laju pembakaran dikarenakan rongga udara pada briket. Namun sedikit berbeda dengan laju pembakaran pada penelitian ini dikarenakan bahwa kerapatan atau tekanan yang diberikan pada semua perlakuan sama yakni $20 \mathrm{~kg} / \mathrm{cm}^{2}$, sehingga laju pembakaran seharusnya sama untuk semua jenis briket. Jadi hal yang sangat berpengaruh mungkin adalah bahan yang digunakan yaitu kotoran ternak.

\subsection{Nilai Kalor}

Nilai kalor atau nilai panas adalah salah satu sifat yang penting untuk menentukan kualitas arang terutama yang berhubungan dengan penggunaannya (Sudiro dan Suroto, 2014). Untuk melihat rataan nilai kalor briket dengan bahan dasar kotoran sapi, kambing dan ayam dengan penambahan sekam padi dapat dilihat pada Gambar 4.

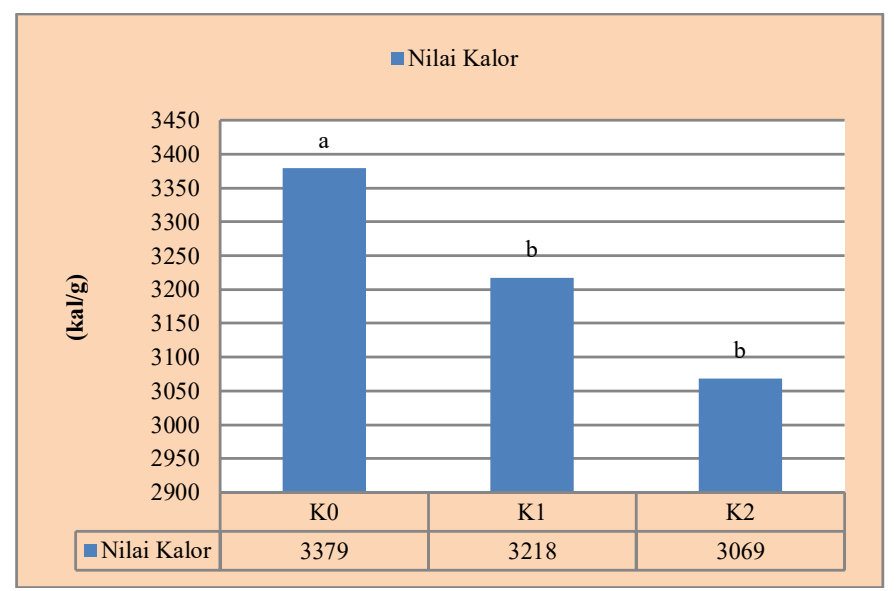

Gambar 4. Rataan Nilai Kalor (Kal/g) dengan Bahan Dasar Kotoran

Sapi,Kambing dan Ayam dengan Penambahan Sekam Padi; Superskrip yang berbeda gambar menunjukkan sangat berbeda nyata $(\mathrm{P}<0,05)$

Gambar 4 menunjukkan nilai kalor briket bioarang tertinggi pada kotoran sapi (K0) yaitu sebesar $3379 \mathrm{kal} / \mathrm{g}$ diikuti briket berbahan dasar kotoran kambing (K1) sebesar $3218 \mathrm{kal} / \mathrm{g}$ dan nilai kalor terendah pada briket berbahan dasar kotoran ayam (K2) terendah $3069 \mathrm{kal} / \mathrm{g}$. Nilai kalor ini pada dasarnya sama dengan yang dihasilkan oleh Suharto et al. (2015) bahwa nilai kalor briket kotoran sapi dengan perekat tepung tapioka $10 \%$ adalah 3.200 $\mathrm{kal} / \mathrm{g}$. Hasil uji statistik menunjukkan bahwa perlakuan ini tidak berpengaruh nyata terhadap nilai kalor yang dihasilkan $(\mathrm{P}>0,05)$. Dari hasil ini kemudian dilakukan uji lanjut dan menunjukkan bahwa K0 berbeda dengan K1 dan K2, K1 tidak berbeda dengan K2. Dapat dijelaskan bahwa bahan baku sangat mempengaruhi nilai kalor, dalam hal ini adalah kotoran ternak dan sekam padi yang dapat dimanfaatkan sebagai sumber energi alternatif pengganti bahan bakar minyak. Sekam memiliki kandungan serat kasar sekitar 35,68\% dan karbohidrat dasar 33,37\% (Suharno 1979 dalam Hartanto dan Alim, 2015).
Kedua limbah ini banyak mengandung karbohidrat terutama jenis cellulosa dan serat-seratan yang sangat potensial untuk sumber karbon yang merupakan penyusun bioarang (Saparudin et al., 2015). Dengan adanya karbon pada masing-masing kotoran ternak tertentu akan berdampak pada nilai kalor yang dihasilkan. Pada Gambar 4 nilai kalor yang dihasilkan sesuai dengan kandungan karbon pada kotoran ternak, dimana kotoran sapi memiliki kandungan karbon 63,44\% lebih besar dari kotoran kambing yakni 46,51\% dan terkecil kandungan karbonnya adalah pada kotoran ayam yakni 42,18\%. Hal ini karena nilai kalor briket dipegaruhi oleh kadar abu briket dan kadar karbon. Semakin tinggi kadar karbon maka nilai kalor briket yang dihasilkan akan semakin tinggi begitu juga sebaliknya, semakin rendah kadar karbon maka nilai kalor yang dihasilkan semakin rendah karena di dalam proses pembakaran membutuhkan karbon yang bereaksi dengan oksigen untuk menghasilkan kalor (Putri dan Andasuryani, 2017).

Dari Gambar 4 dapat dijelaskan bahwa jenis bahan perekat dapat mempengaruhi nilai kalor briket yang dihasilkan. Menurut Utomo dan Primastuti (2013) nilai kalor untuk jenis perekat tepung terigu mempunyai nilai kalor $3455,89 \mathrm{kal} / \mathrm{g}$ dan dibandingkan tepung kanji yang mempunyai nilai kalor $3332,65 \mathrm{kal} / \mathrm{g}$. Hal ini disebabkan karena kadar air pada tepung terigu yakni $12 \%$ yang lebih kecil dari kadar air tepung kanji yakni $15 \%$. Demikian pula ukuran bahan penyusun briket dapat mempengaruhi nilai kalor briket yang dihasilkan. Laporan Utomo dan Primastuti (2013) penggunaan perekat 10\% dengan ukuran partikel 40 mesh menghasilkan nilai kalor 2855,69 kal/g.

Pada penambahan perekat yang semakin tinggi menyebabkan air yang terkandung dalam perekat akan masuk dan terikat dalam pori arang, selain itu penambahan perekat yang semakin tinggi akan menyebabkan briket mempunyai kerapatan yang semakin tinggi pula sehingga pori-pori briket semakin kecil dan pada saat dikeringkan air yang terperangkap di dalam pori briket sukar menguap dan hal ini akan berdampak pada nilai kalor yang dihasilkan.

\section{Simpulan}

Dari penelitan ini dapat disimpulkan bahwa kualitas briket terbaik dihasilkan oleh briket yang dibuat dari bahan dasar kotoran sapi dengan penambahan sekam padi yang menghasilkan kadar air $(35,69 \%)$, kadar abu $(19,72 \%)$ dan nilai kalor (3379 kal/g) sedangkan laju pembakaran terbaik adalah briket kotoran kambing dengan campuran sekam padi $10 \%$.

\section{Pustaka}

Hartanto, F.P dan F. Alim. Optimasi Kondisi Operasi Pirolisis Sekam Padi Untuk Menghasilkan Bahan Bakar Briket Bioarang Sebagai Bahan Bakar Alternatif, Monograph (Tehcnical report). Universitas Diponegoro.

Hendra, D. dan I. Winarni. 2003. Sifat fisis dan kimia briket arang campuran limbah kayu gergajian dan sebetan kayu. Buletin Penelitian Hasil Hutan. 21(3) : 211 - 226. Pusat Penelitian dan Pengembangan Hasil Hutan, Bogor.

Hutasoit, A. 2012, Briket Arang dari Pelepah Salak. [Skripsi]. Fakultas Teknologi Pertanian, Universitas Andalas.

Putri, R. E, dan Andasuryani. 2017. Studi Mutu Briket Arang Dengan Bahan Baku Limbah Biomassa. Jurnal Teknologi Pertanian Andalas, 21 (2) : 143-151.

Rahman, B. N. Onu, F. dan Sudarjo. 2010. Pengukuran Nilai Kalor Bahan Bakar Briket Arang Kombinasi Cangkang Pala (Myristica Fragan Houtt) dan Limbah Sawit (Elaeis Guenensis). Seminar Nasional Teknik Mesin Universitas Muhammadiyah Yogyakarta. Hal. 104-115.

Riseanggara. 2008. Optimasi kadar perekat pada briket limbah biomasa. Bogor, perpustakaan Institut Pertanian Bogor.

Saparudin., Syahrul dan Nurchayat. 2015. Pengaruh Variasi Temperatur Pirolisis Terhadap Kadar Hasil Dan NilaiKalor Briket Campuran Sekam Padi-Kotoran Ayam. Dinamika Teknik Mesin, 5 (1): 17-24.

Sarjono dan M, Ridlo. 2013. Studi eksperimentasl penggunaan kotoran sapi sebagai bahan bakar alternatif. Majalah ilmiah STTR Cepu, 16 (11) : 1221.

Subroto. 2007. Karakteristik Pembakaran Briket Campuran Arang Kayu dan Jerami. Jurnal Media Mesin. 8 (1): 10-16.

Sudiro dan S. Suroto. 2014. Pengaruh Komposisi dan Ukuran Serbuk Briket yang terbuat dari Batubara dan Jerami Padi Terhadap Karakteristik Pembakaran. Jurnal Sainstech Politeknik Indonusa Surakarta, 1 (2) : 1 18.

Suding dan Jamaludin. 2015. Pengaruh Jumlah Perekat Kanji terhadap Lama Briket Terbakar menjadi Abu. Jurnal Chemica, 16 (1): 27 - 36.

Suharto, B., A.T.S, Haji dan Sunarsih. 2015. Uji Kualitas Briket Kotoran Sapi Pada Variasi Kadar Perekat Tapioka dan Suhu Pengeringan. Jurnal Sumberdaya Alam dan Lingkungan,39-44.

Syahrul., Y. A. Padang dan N. Sakban. 2015. Pengaruh Kombinasi Limbah Kotoran Ternak Ayam denganlimbah Sekam Padi Terhadap Kualitas Bioarang. Dinamika Teknik Mesin, 5 (2) : 122-130. 
Utomo, A. F dan N, Primastuti. 2013 . Pemanfaatan Limbah Furniture Enceng Gondok (Eichornia Crassipes) di Keon Gallery Sebagai Bahan Dasar Pembuatan Briket Bioarang. Jurnal teknik kimia dan industri, 2 (2) :220225.

Widodo, I.G., Sutriyatna dan E. Ignatius. 2010. Upaya Penerapan Teknologi Pengolahan Arang Tempurung Kelapa untuk Meningkatkan Nilai Tambah Petani Di Kecamatan Sei Raya Kabupaten Bengkayang. Jurnal IPREKAS- Ilmu Pengetahuan dan Rekayasa, Mei 2010. 